\title{
Public and Household Spending in Private, Publicly-Funded Private and Public Schools in Spain during the Economic Crisis (2007-2012)
}

\section{Gasto público y de las familias según tipo de centro educativo en España durante la crisis económica (2007-2012)}

Mario Andres-Candelas (1) mario.andres.candelas@gmail.com

Jesús Rogero-García (2) jesus.rogero@uam.es

(1) Universidad Complutense de Madrid

(2) Universidad Autónoma de Madrid

(Received: December 17, 2016; accepted for publishing: March 10, 2017)

How to cite: Andres-Candelas, M. y Rogero-García, J. (2019). Public and household spending in private, publicly-funded private and public schools in Spain during the Economic Crisis (2007-2012). Revista Electrónica de Investigación Educativa, 21, 1-15. doi:10.24320/redie.2019.21.e18.1756

\begin{abstract}
In Spain, the economic crisis was characterised by cut-backs in public spending on education services and a reduction in households' purchasing power. This article aims: (1) to analyse public spending per student in private, publicly-funded private and public schools from 2007 to 2012; (2) to determine whether household spending on education per student rose in that period; and (3) to ascertain whether the differences among types of school by their students' socio-economic backgrounds varied in the period studied. Public spending for public and publicly-funded private schools was cut back and increased for private schools. Household spending rose in public and in private institutions and was stable in publiclyfunded private schools. Inter-category differences in the breakdown of student bodies by socio-economic background were not observed to change.
\end{abstract}

Keywords: Education policy, publicly-funded private schools, public spending, household spending, economic crisis.

\section{Resumen}

La crisis económica en España se ha caracterizado por una reducción del gasto público en educación y por una reducción de la capacidad adquisitiva de las familias. Este artículo tiene como objetivo: 1) analizar cómo ha evolucionado el gasto público en los centros privados, concertados y públicos entre los años 2007 y 2012; 2) estimar si ha aumentado el gasto educativo de las familias en ese período; y 3) conocer si las diferencias en la composición socioeconómica del alumnado según tipo de centro han variado. El gasto público se redujo para los centros públicos, mientras que aumentó para los centros concertados y privados. El gasto de las familias aumentó significativamente para todos los centros. Las diferencias en la composición socioeconómica del alumnado en los diferentes tipos de centro se han mantenido estables.

Palabras clave: Política educativa, centros privados subvencionados, gasto público, gasto privado, crisis económica. 


\section{Introduction}

The effectiveness of investment in education depends not only on the amount, but also the composition of the investment (Hanushek, 2013). One of the most prominent issues in that regard concerns the share of private capital in compulsory education (Burch, 2009). In recent decades, governments have implemented policies to encourage the privatisation of education investment and management in increasingly varied ways (Ball, 2014). These approaches, which include so-called exogenous privatisation, under which privately owned schools (known as 'charter schools' or 'academies' in the US and the UK, respectively, and 'centros concertados' in Spain) receive substantial public funding, have had profound implications for the efficiency and equity of the education system (Ball \& Youdell, 2007). Despite their prominence in Spain, these budgetary dynamics have not been sufficiently studied. More specifically, no research has been conducted on whether, during the economic crisis (in Spain, GDP contracted by $6.1 \%$ as unemployment rose from 8.6 to 25.8\% between 2007 and 2012), funds were redirected toward privately owned institutions, whether that has translated into a heavier burden on households and as a corollary, greater uniformity in the socio-economic backgrounds of student bodies in each type of school.

This study aims to fill that gap. Its objective is to determine the trends in public, publicly-funded private and private school funding in the early years of the economic crisis in Spain, and the possible effects on the composition of the respective student bodies. This paper aims to: (1) compare public spending per student in early childhood education, primary and secondary education (low and upper secondary and vocational training) in public, publicly financed private and private independent schools from 2007 to 2012; (2) estimate household spending on education in these three categories of schools in 2007-2012; (3) estimate total (public and private) spending by type of school in 2007-2012; and (4) establish trends in the concentration of students with similar socio-economic backgrounds in the three types of schools. The ultimate aim is to ascertain how education policy has reacted to the economic crisis and identify the possible implications of that policy for student social segregation in the Spanish education system.

\subsection{The co-existence of public, publicly-funded private and private schools}

Three types of schools can be identified in Spain: public (government-owned, -funded and -operated), publicly-funded private (government-funded, privately owned and operated) and private (privatelyfunded, -owned and -operated) (Jacott \& Maldonado 2006). Since 1985, publicly-funded private schools have been receiving public funds in exchange for meeting a series of requirements set out in the national legislation (Constitutional Act 8/1985): they must cover a community demand for schooling, be tuitionfree, apply the same conditions for admission as public schools and offer any religious activities on a voluntary basis. In keeping with the conservative party's (Partido Popular) support for publicly-funded private schools, the most recent education act (Constitutional Act 8/2013) contains provisions for expanding their number (Bayona, 2013).

Spain has a larger proportion of such schools than other countries. In 2012, the percentage of students enrolled in such institutions was much higher than the OECD mean both in primary (28 compared to $8 \%$ ) and lower secondary (29 compared to $11 \%$ ) education (OECD, 2014). In upper secondary schooling, the Spanish numbers were somewhat lower than the mean (12 versus $14 \%$ ). Enrolment in private schools was slightly higher than the OECD mean percentage (4 as opposed to $3 \%$ ) in primary, the same as the mean in lower secondary (3\%) and much higher than the mean in upper secondary (9 versus $5 \%$ ) education.

In Spain, households with students in publicly-founded private schools face significantly higher education expenses than those whose children attend public schools (Villarroya, 2003). These higher expenses are both direct, in the form of fees (Mancebón-Torrubia \& Pérez-Ximénez, 2007), and indirect, such as charges for bussing or meals. In other European countries with high percentages of students enrolled in government-dependent private schools, such as Netherlands, Denmark or Sweden, the prohibition to charge households for services is effectively enforced (Patrinos, 2013; Wiborg, 2013) and cost differences are non-existent or negligible. In the United States, where charging households extra fees is also banned, 
government-dependent private schools raise the funds needed to cover shortfall through sponsorship and outside philanthropy (Forman, 2007).

\subsection{School funding models and their effects on the education system}

The debate around funding educational institutions has intensified in recent years against a backdrop of cut-backs in European public spending (Eurydice, 2013). In Spain, it focuses on the distribution of public investment between the two types of publicly funded schools, public and publicly-founded private. The voices in favour of expanding the latter contend that it is a cheaper option for governments and guarantees parents the freedom to choose the educational model they want for their children (PérezDíaz \& Rodríguez, 2011). The advocates of extending public schooling hold that this option enhances system equity and reduces educational inequality with no detriment to quality (Fernández \& Muñiz, 2012). Consequently, exploring the effects of the model in place for funding educational institutions is a worthwhile exercise.

The school funding model impacts the financial resources devoted by households to schooling. More specifically, educational co-payments for compulsory education, whether legal or otherwise, have significant implications. Higher household outlays for compulsory education have been shown to lead to higher absenteeism and drop-out rates (Mehrotra \& DelaMonica, 1998; UNESCO, 2008).

Another area that has been researched is academic performance by type of school. In absolute terms, private and publicly-founded private schools score higher. In Spain, however, after controlling for students' socio-economic backgrounds, most studies conclude that the differences are not significant (Cordero, Crespo \& Pedraja, 2013). Research comparing the academic performance by type of school in other countries likewise fails to yield conclusive results (Choi \& Calero, 2012; Dronkers \& Avram, 2010).

Studies have also been conducted on the effects of the school funding model on the social composition of the student body. All these factors would largely explain the differences in raw academic scores (Sirin, 2005).

Student backgrounds in schools with mixed funding depend largely on each country's regulations. In Spain, even though they are formally required to apply the same admission standards as public schools (Salinas \& Santín, 2012), publicly-founded private schools have a considerable share of students from medium- or high-income households and higher schooling (Escardíbul \& Villarroya, 2009; MancebónTorrubia \& Pérez-Ximénez, 2010), as well as of students of national origin (Choi \& Calero, 2012; Salinas \& Santín, 2012). Spain is the OECD country where the gap between public and publicly-funded private schools by parents' level of schooling is widest (Pérez-Díaz \& Rodríguez, 2011). This trend has also been observed in countries such as Chile (OECD, 2012). Spain is also among the OECD countries with the highest rate of social segregation between Secondary Schools and where the share of segregation accounted for by school type (public or private) is highest (23\%) (Jenkins, Micklewright, \& Schnepf, 2008). Most students of foreign origin are enrolled in public schools, where they account for $12.1 \%$ of the total, whereas in publicly-funded private schools the percentage is $5.4 \%$ (García, Olmos, Rubio y Capellán, 2014). Due to such a conspicuous difference in composition, the 'peer effect' on individual performance (Ammermueller \& Pischke, 2009) is beneficial in private and publicly-funded private schools and adverse in public schools.

The differences in student background are largely down to the variability in education costs and the establishment of other selection mechanisms (Bonal, 2002; Villarroya, 2003; Mancebón-Torrubia \& PérezXiménez, 2007). The choice of a school is therefore related to cost and a household's income level (Alderman, Orazem, \& Paterno, 2001). Other economic and social dynamics also affect segregation into type of school, such as geographic or macroeconomic factors (Williams \& Rossiter, 2004). More specifically, the degree of socio-economic segregation varies, at least in part, with the business cycle (measured in terms of GDP): in downturns the difference tends to narrow, along with families' de facto options (Gorard, Hordosy \& See, 2013). 
Lastly, the spending required for the three funding models has likewise been the object of study. Private schools call for less government spending, inasmuch as they are essentially maintained with private resources. In Spain, publicly-funded private schools cost governments less than public schools because the expense is only partly defrayed with public funds. In 2007, non-university public spending per student in publicly-funded private schools amounted to $49.8 \%$ of the spending per student in public schools (Rogero-García \& Andrés-Candelas, 2014). International research has also shown that, generally speaking, publicly-funded private schools cost governments less (Mourshed, Chijioke \& Barber, 2010). In the United States, for instance, government-dependent private schools are allocated from 60 to $80 \%$ of the amount per student allocated to public schools (Dynarski et al., 2010). As a result, such schools need to raise funds from other sources. In Spain, much of the difference is assumed by households: in, 2007 households with students in public schools spent just $38.7 \%$ of the amount spent by households with children attending publicly-funded private schools (Rogero-García \& Andrés-Candelas, 2014).

Such differences depend on public policy. In Sweden, Netherlands and Poland, public and publicly-funded private schools compute their budgets in the same manner and receive the same amount of money (Eurydice, 2013). In Sweden, with $9 \%$ of primary school, $14 \%$ of lower secondary school and $17 \%$ of upper secondary school students in publicly-funded private schools (OECD, 2014), household spending on non-university education is very close to nil, whereas in Spain it amounts to nearly $9 \%$ of the total (OECD, 2014). Such data reveal the importance of regulating and monitoring public funding of private schools.

\section{Method}

This study analysed public and household spending per student for early childhood education, primary and secondary education by type of school: public, publicly-funded private and private. It also researched the extent to which each type of institution is characterised by certain percentages of students from given socio-economic backgrounds.

The spending per capita figures were estimated on the grounds of the number of students enrolled in academic years 2006/07 and 2011/2012 (Table I). Household spending on education was drawn from the National Statistics Institute's household spending on education survey (Encuesta sobre Gasto de los Hogares en Educación), one of the sections of its household budget survey (Encuesta de Presupuestos Familiares). As to date this survey has only been conducted for 2007 and 2012, these were the two years chosen for the comparison. The sample included 3,299 households in 2007 and 5,607 in 2012.

Table I. Number of students by level of schooling and school ownership (academic years 2006/2007 and 2011/2012)

\begin{tabular}{l|c|c|c|c|c|c|c|c}
\cline { 2 - 9 } & \multicolumn{2}{c}{ Total } & \multicolumn{2}{c|}{ Public schools } & \multicolumn{2}{c|}{$\begin{array}{c}\text { Publicly-funded } \\
\text { private schools }\end{array}$} & \multicolumn{2}{c}{ Private schools } \\
\cline { 2 - 9 } & $2006 / 07$ & $2011 / 12$ & $2006 / 07$ & $2011 / 12$ & $2006 / 07$ & $2011 / 12$ & $2006 / 07$ & $2011 / 12$ \\
\hline $\begin{array}{l}\text { First and second level } \\
\text { early childhood } \\
\text { education and primary }\end{array}$ & $4,095,290$ & $4,715,040$ & $2,701,231$ & $3,134,257$ & $1,118,978$ & $1,267,551$ & 275,081 & 313,232 \\
$\begin{array}{l}\text { Secondary (lower, } \\
\text { vocational, upper) }\end{array}$ & $2,964,501$ & $3,176,020$ & $2,062,065$ & $2,241,960$ & 726,682 & 742,891 & 175,754 & 191,169 \\
Total & $7,059,791$ & $7,891,060$ & $4,763,296$ & $5,376,217$ & $1,845,660$ & $2,010,442$ & 450,835 & 504,401 \\
\hline
\end{tabular}

Source: authors' formulation from Spanish Ministry of Education, Culture and Sport statistics on non-university education (Estadísticas de las Enseñanzas no Universitarias), academic years 2006/2007 and 2011/2012.

Public spending on public and publicly-funded private schools was estimated by analysing the data in the Spanish Ministry of Education, Culture and Sport's statistics on public spending on education (Estadística del Gasto Público en Educación) and its statistics on scholarships and book and materials allowances for students (Estadística de Becas y Ayudas al Estudio). The data for government-independent private schools were taken from the National Statistics Institute's funding and spending on private education 
survey (Encuesta de financiación y gastos de la enseñanza privada) for academic years 2004/2005 and 2009/2010. A total of 6477 schools were analysed in 2005 and 8,028 in 2010. For the intents and purposes of comparison, the values for those two years were assumed to have remained constant in 2007 and 2012, respectively.

Public spending on government-independent private schools was defined to consist solely of public subsidies transferred directly to these institutions. It consequently excluded households' subsidies and tax deductibles. Publicly-funded private school spending comprised the sums chartered and public school spending, teaching activities; the items for scholarships and book and material allowances, extracurricular activities and ancillary services were re-calculated. These calculations are summarised in the formula below, taken from Rogero-García \& Andrés-Candelas (2014):

$$
P S S=\frac{A E+S C+A E X+B T M+B C R+C S}{N A}
$$

where:

PSS Public spending per early chilhood education, primary and secondary school student is public spending on early chilhood education, primary and secondary school teaching: academic and non-academic staff salaries, goods and services, investment, and at- and out-of-

$A E$ school psychopedagogical consultants. In publicly-funded private schools, this is the sum specified for education in the respective charters. In 2007, the types of spending per publiclyfunded private classroom included academic staff salaries and variable and other expenses. is public spending on ancillary services for early chilhood education, primary and secondary $S C$ place of residence (scholarships and other types of allowances are not included in these items).

is public spending on early chilhood education, primary and secondary extracurricular and

AEX supplementary activities: educational (cultural, artistic, social, sports or recreational) but not strictly academic activities, and allocations for encouraging sport in school.

is public spending on early chilhood education, primary and secondary education students'

BTM scholarships and allowances for books and materials in public and publicly-funded private schools.

$B C R$ is public spending on bussing, meals and rooming for early chilhood education, primary and secondary education students in public and publicly-funded private schools.

CS is public spending on social expenses (payroll tax) attributable to early chilhood education, primary and secondary education (for public schools only).

$N A$ is the number of students enrolled in early chilhood education, primary and secondary education.

In other words, items not relevant to the comparison were excluded, such as: general administration, educational research, compensatory education, out-of-school extracurricular activities and teacher training, inasmuch as such investment impacts all schools directly or indirectly. Expenses for special and adult education and education abroad were also excluded, for they are unrelated to early chilhood education, primary and secondary school funding.

The amounts devoted by households to out-of-school extracurricular activities were excluded, for these activities are outside the education system. Household (private) spending on education was calculated as follows for both types of schools. 


$$
H S S=C L+A E+S C+B S
$$

where:

HSS Household spending per student on early chilhood education, primary and secondary education. is household spending per student on academic lessons, including both classroom (cost-free in

$C L$ public and publicly-funded private schools, for second level early chilhood education, primary and lower secondary education) and voluntary supplementary teaching.

$A E$ is household spending per student on at-school (support and leisure) extracurricular activities.

$S C$ is household spending per student on ancillary services (meals, rooming, bussing).

$B S$ is household spending per student on goods and services (books, uniforms and similar).

According to the INE, or the Spanish Statistics Institute, the Consumer Price Index increased $14 \%$ between 2007 and 2012 and 8.4\% between 2007 and 2010 (yearly means). To compare values, a Consumer Price Index Deflator (2007=100) was applied for 2010 and 2012 calculations.

The information for analysing the socio-economic composition of the student body was drawn from the Programme for International Student Assessment (PISA) 2006 and 2012 databases for Spain. The family background information on 15-year-old students in different countries in this database is particularly well suited for such an analysis (Jenkins, Micklewright, \& Schnepf, 2008). Given that socio-economic segregation patterns are similar in primary and secondary education (Gorard, Hordosy \& See, 2013), the PISA data may be regarded as appropriate for analysing the two stages jointly, as in this study.

The PISA information distinguishes among three categories of schools: privately owned schools with less than $50 \%$ public funding (here called private or government-independent schools), private schools with over 50 \% funding from public sources (publicly-funded private or government-dependent schools) and publicly owned and run schools (public schools) (OECD, 2013). Three socio-economic background indicators were used: two (the mean and the median) from the ESCS (economic, social and cultural status) index, in turn based on the following variables: the International Socio-Economic Index of Occupational Status, parents' highest schooling measured in years, the PISA index of family wealth, the PISA index of home educational resources, and the PISA index of possessions related to 'classical' culture in the family home (OECD, 2002); and the third, the percentage of mothers with an upper secondary school diploma or university degree (3A, 3B or 3C schooling). The objective was to obtain more accurate information on students' socio-economic background by type of school. 


\section{Results}

In 2007, public spending per student in public schools amounted to 5,348 euros and in 2012 to 4,045 euros (in constant 2007 euros) (Table II). Public spending in publicly-funded private schools desdenced from 2,670 euros in 2007 to 2,380 euros in 2012. Private schools received 182 euros in 2007 and 413 in 2012. In both years, public schools devoted over $80 \%$ and publicly-funded private schools over $90 \%$ of this spending to academic lessons.

Table II. Yearly public spending per student by educational level and school ownership (euros)

\begin{tabular}{|c|c|c|c|c|c|c|c|c|}
\hline & \multicolumn{2}{|c|}{$\begin{array}{l}\text { Total in publicly } \\
\text { funded schools }\end{array}$} & \multicolumn{2}{|c|}{ Public schools } & \multicolumn{2}{|c|}{$\begin{array}{l}\text { Publicly-funded } \\
\text { private schools }\end{array}$} & \multicolumn{2}{|c|}{$\begin{array}{l}\text { Private } \\
\text { schools (1) }\end{array}$} \\
\hline & 2007 & 2012 & 2007 & 2012 & 2007 & 2012 & 2005 & 2010 \\
\hline Academic lessons & 4,030 & 3,060 & 4,609 & 3,345 & 2,536 & 2,298 & & . \\
\hline $\begin{array}{l}\text { First and second level early } \\
\text { childhood education and primary }\end{array}$ & 3,532 & 2,692 & 4,046 & 2,980 & 2,291 & 1,980 & . & . \\
\hline $\begin{array}{l}\text { Secondary (lower, vocational, } \\
\text { upper) }\end{array}$ & 4,713 & 3,603 & 5,347 & 3,855 & 2,913 & 2,841 & . & . \\
\hline Ancillary services & 101 & 101 & 140 & 138 & 0 & 0 & & . \\
\hline $\begin{array}{l}\text { Extracurricular and } \\
\text { supplementary activities }\end{array}$ & 83 & 44 & 83 & 44 & 83 & 44 & . & . \\
\hline $\begin{array}{l}\text { Scholarships and book } \\
\text { and materials allowances }\end{array}$ & 22 & 22 & 23 & 25 & 17 & 15 & & . \\
\hline $\begin{array}{l}\text { Support for meals, bussing } \\
\text { and rooming }\end{array}$ & 42 & 34 & 46 & 39 & 34 & 23 & & . \\
\hline Social expenses (payroll tax) & 322 & 330 & 447 & 454 & 0 & 0 & . & . \\
\hline Total & 4,600 & 3,591 & 5,348 & 4,045 & 2,670 & 2,380 & 182 & 413 \\
\hline
\end{tabular}

(1) Private schooling includes only public subsidies paid directly to educational institutions and hence excludes household subsidies or tax deductibles.

Note: Constant 2007 euros.

(.) No data breakdown available.

Source: Spanish Ministry of Education statistics on public spending on education and its statistics on scholarships and study allowances (Estadística del Gasto Público en Educación and Estadística de Becas y Ayudas al estudio) academic years 2006/2007, 2011/2012. National Statistics Institute's survey on private education funding and expenses (Encuesta de financiación y gastos de la enseñanza privada), academic years 2004/2005 and 2009-2010.

Table III gives household spending on education by type of school in 2007 and 2012 (in constant 2007 euros). Spending per student in public schools was 473 euros in 2007 and 527 euros in 2012, and 1,222 and 1,212 euros in publicly-funded private schools in 2007 and 2012, respectively. Spending in private schools rose from 2,678 euros in 2007 to 2,891 euros in 2012. In public and publicly-funded private schools, the highest expense in both primary and secondary education was for goods and services. The rise in ancillary service costs was particularly striking: in public primary schools it grew from 142 euros in 2007 to 236 in 2012 and from 29 to 75 in secondary schools, respectively. In publicly-funded private schools, ancillary services rose from 328 to 457 euros in primary and from 144 to 245 in secondary education. In private schools, the costliest item in both years was academic lessons. 
Table III. Yearly household spending on educational goods and services by educational level and school ownership (euros); Spain, 2007-2012

\begin{tabular}{|c|c|c|c|c|c|c|c|c|c|c|}
\hline & \multicolumn{2}{|c|}{$\begin{array}{l}\text { Public } \\
\text { schools }\end{array}$} & \multicolumn{2}{|c|}{$\begin{array}{l}\text { Publicly- } \\
\text { funded pri- } \\
\text { vate schools }\end{array}$} & \multicolumn{2}{|c|}{ Private schools } & \multicolumn{2}{|c|}{$\begin{array}{l}\% \text { Public / publicly- } \\
\text { funded private }\end{array}$} & \multicolumn{2}{|c|}{$\begin{array}{l}\% \text { Public/ } \\
\text { private }\end{array}$} \\
\hline & 2007 & 2012 & 2007 & 2012 & 2007 & 2012 & 2007 & 2012 & 2007 & 2012 \\
\hline \multicolumn{11}{|l|}{ Early childhood education and primary } \\
\hline Total & 538 & 650 & 1,375 & 1,329 & 2,407 & 2,466 & 39.1 & 48.9 & 22.4 & 26.4 \\
\hline Academic lessons & 39 & 32 & 391 & 315 & 1,573 & 1,484 & 10.0 & 10.1 & 2.5 & 2.1 \\
\hline Ancillary services (meals, rooming, bussing) & 142 & 236 & 328 & 457 & 337 & 694 & 43.3 & 51.6 & 42.1 & 34.0 \\
\hline Goods and services (books, uniforms...) & 318 & 351 & 557 & 477 & 429 & 244 & 57.1 & 73.5 & 74.1 & 143.7 \\
\hline Secondary & & 0 & & 0 & & 0 & & & & \\
\hline Total & 387 & 354 & 987 & 1,011 & 3,101 & 3,589 & 39.2 & 35.0 & 12.5 & 9.9 \\
\hline Academic lessons & 18 & 25 & 267 & 278 & 2,040 & 2,491 & 6.7 & 9.0 & 0.9 & 1.0 \\
\hline (Cultural and recreational) at-school extracurricular activities & 7 & 6 & 37 & 43 & 51 & 75 & 18.9 & 14.0 & 13.7 & 8.0 \\
\hline Goods and services (books, uniforms...) & 333 & 249 & 539 & 445 & 666 & 348 & 61.8 & 55.8 & 50.0 & 71.4 \\
\hline Total spending & 473 & 527 & 1,222 & 1,212 & 2,678 & 2,891 & 38.7 & 43.5 & 17.7 & 18.2 \\
\hline
\end{tabular}

Note: Constant 2007 euros.

Source: National Statistics Institute's survey on household spending on education (Encuesta sobre el Gasto de los Hogares en Educación) and Spanish Ministry of Education's statistics on public spending on education (Estadística del Gasto Público en Educación) for a number of years.

Public spending per student declined $24 \%$ on public schools and $11 \%$ on publicly-funded private and rose $148 \%$ on private schools (Table IV). Household spending rose $11 \%$ in public schools and $8 \%$ in private schools and descended $1 \%$ in publicly-funded private schools. As a result, total spending dropped $21 \%$ and $8 \%$ on public and publicly-funded private schools, respectively, and rose $15 \%$ on private schools. Whilst the total spending per student in publicly-funded private schools came to $66.9 \%$ of spending in public schools in 2007, by 2012 it had climbed to $78.6 \%$. The rise was even steeper in private schools, from $49.1 \%$ in 2007 to $71.7 \%$ in 2012. 
Table IV. Yearly spending per student (euros); Spain, 2007/2012

\begin{tabular}{|c|c|c|c|c|c|c|c|c|c|c|c|c|c|c|c|}
\hline & \multicolumn{5}{|c|}{ Public spending per student } & \multicolumn{5}{|c|}{ Household spending per student } & \multicolumn{5}{|c|}{$\begin{array}{c}\text { Total spending (public + household) } \\
\text { per student }\end{array}$} \\
\hline & $\begin{array}{l}\text { Pub. } \\
\text { schools }\end{array}$ & $\begin{array}{l}\text { Publicly- } \\
\text { funded } \\
\text { private } \\
\text { schools } \\
\end{array}$ & $\begin{array}{l}\text { Priv. } \\
\text { schools }\end{array}$ & $\begin{array}{c}\% \\
\text { pub.funded/ } \\
\text { pub. }\end{array}$ & $\begin{array}{c}\% \\
\text { priv. } \\
\text { /pub. }\end{array}$ & $\begin{array}{c}\text { Pub. } \\
\text { schools }\end{array}$ & \begin{tabular}{|l|} 
Publicly- \\
funded \\
private \\
schools \\
\end{tabular} & $\begin{array}{l}\text { Priv. } \\
\text { schools }\end{array}$ & $\begin{array}{c}\% \\
\text { priv. } \\
\text { /pub. }\end{array}$ & $\begin{array}{l}\text { \% priv./ } \\
\text { pub.funded }\end{array}$ & $\begin{array}{l}\text { Pub. } \\
\text { schools }\end{array}$ & \begin{tabular}{|l|} 
Publicly- \\
funded \\
private \\
schools \\
\end{tabular} & $\begin{array}{l}\text { Priv. } \\
\text { schools }\end{array}$ & $\begin{array}{c}\% \\
\text { pub.funded } \\
\text { /pub. }\end{array}$ & $\begin{array}{c}\% \\
\text { priv. } \\
\text { /pub. }\end{array}$ \\
\hline 2007 & 5,348 & 2,670 & 182 & 49.9 & 3.4 & 473 & 1,222 & 2,678 & 17.7 & 45.6 & 5,821 & 3,892 & 2,860 & 66.9 & 49.1 \\
\hline 2012 & 4,045 & 2,380 & 413 & 58.9 & 10.2 & 527 & 1,212 & 2,891 & 18.2 & 41.9 & 4,572 & 3,591 & 3,279 & 78.6 & 71.7 \\
\hline $\begin{array}{l}\text { Difference } \\
\text { 2012-2007 }\end{array}$ & $-1,303$ & -290 & 231 & 8.9 & 6.8 & 54 & -10 & 213 & 0.6 & -3.7 & $-1,249$ & -301 & 419 & 11.7 & 22.6 \\
\hline $\begin{array}{l}\text { Growth, } \\
2007-2012 \\
(\%)\end{array}$ & -24 & -11 & 127 & & & 11 & -1 & 8 & & & -21 & -8 & 15 & & \\
\hline
\end{tabular}

Note: Constant 2007 euros.

Source: Spanish Ministry of Education's statistics on public spending on education (Estadística del Gasto Público en Educación) and statistics on scholarships and study allowances (Estadística de Becas y Ayudas al estudio); National Statistics Institute's survey on household spending on education (Encuesta sobre el Gasto de los Hogares en Educación) for a number of years.

At 0.12 , the mean Escs index followed an upward trend for all students as a whole (Table V). Broken down by type of school, it declined by 0.17 from 2006 to 2012 for students in private schools and rose by 0.18 for students in publicly-funded private and public schools. The median followed a similar pattern. The percentage of mothers in levels 3A, 3B or 3C rose in all types of schools, and particularly in publicly-funded private $(14.5 \%)$ and public $(13.1 \%)$ institutions. 
Table V. Socio-economic background by type of school

\begin{tabular}{l|c|c|c|c|c|c|c|c|c} 
& \multicolumn{2}{c|}{$\begin{array}{c}\text { Mean economic, social } \\
\text { and cultural status index }\end{array}$} & \multicolumn{2}{c|}{$\begin{array}{c}\text { Median economic, social } \\
\text { and cultural status index }\end{array}$} & \multicolumn{3}{c}{$\begin{array}{c}\text { Mothers in levels 3A, } \\
\text { 3B, 3C (\%) }\end{array}$} \\
\cline { 2 - 11 } & 2006 & 2012 & Dif. & 2006 & 2012 & Dif. & 2006 & 2012 & Dif. \\
\hline Private schools & 0.72 & 0.55 & -0.17 & 0.86 & 0.77 & -0.09 & 80.6 & 81.4 & 0.9 \\
Publicly-funded private schools & -0.88 & 0.10 & 0.18 & -0.12 & 0.15 & 0.27 & 55.4 & 69.9 & 14.5 \\
Public schools & -0.57 & -0.39 & 0.18 & -0.66 & -0.47 & 0.19 & 39.1 & 52.3 & 13.1 \\
\hline Total & -0.32 & -0.20 & 0.12 & -0.39 & -0.24 & 0.15 & 47.5 & 58.8 & 11.3 \\
\hline
\end{tabular}

Source: PISA 2006 and 2012 microdata.

The difference in the composition of public and publicly-funded private school student bodies remained stable between 2006 and 2012 when measured as the mean ESCS index and widened slightly (0.08) when measured by the median. A significant decline in the difference in the composition between public and government-independent private schools was observed in the three indicators analysed (Table VI). The difference in the mean ESCS index dropped by 0.35 , the median by 0.28 and the percentage of mothers with highest schooling $3 \mathrm{~A}, 3 \mathrm{~B}$ or $3 \mathrm{C}$ by $12.29 \%$.

Table VI. Differences in socio-economic backgrounds of students enrolled in public, publicly-funded private and private schools

\begin{tabular}{l|c|c|c|c|c|c}
\cline { 2 - 7 } & \multicolumn{3}{c|}{$\begin{array}{c}\text { publicly-funded private } \\
\text { schools - public schools }\end{array}$} & \multicolumn{3}{c}{ Private schools - Public schools } \\
\cline { 2 - 7 } & 2006 & 2012 & $\begin{array}{c}\text { Variation, } \\
2006-2012\end{array}$ & 2006 & 2012 & $\begin{array}{c}\text { Variation, } \\
2006-2012\end{array}$ \\
\hline Mean ESCS & 0.49 & 0.49 & 0.00 & 1.29 & 0.94 & -0.35 \\
Median ESCS & 0.54 & 0.62 & 0.08 & 1.52 & 1.24 & -0.28 \\
Schooling: mother in levels 3A-3C (\%) & 16.2 & 17.6 & 1.39 & 41.4 & 29.1 & -12.29 \\
\hline
\end{tabular}

Source: PISA 2006 and 2012 microdata.

\section{Discussion}

Any debate around the effects of public and private investment in education and exogenous privatisation (Ball \& Youdell, 2007) calls for accurate and reliable information. This study is the first comprehensive and comparable analysis of the trends in public and household funding for education in Spain and the differences between the socio-economic compositions of the student body ofschools in a period of intense social change: the early years of the economic crisis that began in 2008.

It reviews the pattern of the country's public spending by type of school. Between the two years studied, 2007 and 2012, total public spending for education declined significantly (Ministerio de Educación, Cultura y Deporte, 2014). The findings show that this cut-back primarily affected public schools. That notwithstanding, as in other countries with government-dependent private schools, publicly-funded private schools continued to cost governments less than public schools (Mourshed, Chijioke \& Barber, 2010).

That lower cost can be primarily attributed to two factors. The first is teachers' working conditions, including salaries and the teacher/student ratio. Private and publicly-funded private school teachers earn less than their public school counterparts (Valverde, 2004). Furthermore, the teacher/student ratio was $18.2 \%$ lower in the public system in academic year 2011/2012: 10.9 in public schools versus 13.4 in private schools (with or without public funding). The second is related to school location. The public system meets schooling needs in rural areas, where the cost per student enrolled is higher (Pérez-Díaz \& 
Rodríguez, 2011).

The findings of this study show a significant rise in public funding for private schools through subsidies and other expense items. Consequently, private school dependence on public funding grew in the early years of the economic crisis. These data, indicative of a trend toward privatisation of education in Spain, are consistent with the factors identified in the literature as drivers of private funding models: (a) educational de-centralisation (Zajda, 2006): competence for education was incumbent upon the regions; (b) conservative party governance (Wolf \& Zohlnhöfer, 2009): the Partido Popular, a conservative, neoliberal party, governed in most regions; and (c) economic crisis (Hartley, 2010; Narodowski \& Moschetti, 2015).

In relation to findings on household spending on education, those with students attending public or private schools increased theirs significantly in the period analysed despite their lower spendable income due to the recession (Herrero, Soler \& Villar, 2013), while for those attending publicly-funded private schools it held steady. This might point to how households of students attending public schools responded to the significant fall in public spending. The particularly striking contrast between the gross spending of households with students in one and the other category of publicly-funded schools both years revealed the extent to which publicly-funded private schools receive payments from households and the public administration (Mancebón-Torrubia \& Pérez-Ximénez, 2007) contrary to practices in other European countries (Patrinos, 2013; Wiborg, 2013) and the United States (Forman, 2007). Even where these differences adopt the form of voluntary donations for education services (Mehrotra \& DelaMonica, 1998), they induce inequalities. It remains to be seen whether these higher expenses are related to higher absenteeism and drop-out rates among students from lower income families in Spain, as they have been suggested to be in other countries (UNESCO, 2008).

The information on total (public and household) estimated spending per student in different types of schools and the trend in the period studied is likewise enlightening. The data show that the differences in the cost of the three types of school narrowed significantly, due essentially to the more intense cut-backs in public investment in public schools. The upturn was particularly steep in private schools where overall spending in 2012 was close to spending on publicly-funded private schools. Another trend worthy of note was the growing share of household spending in the total funding for education in Spain.

Lastly, this study explores whether, with the aforementioned variations in school funding, the differences between types of school in student body breakdown by socio-economic background changed and in particular whether the proportion of students from lower income households rose in public schools. The analysis based on PISA (2006 and 2012) data revealed that the ESCS index and other indicators of public and publicly-funded private school students' social economic status improved, while the status of students enrolled in private schools was unaltered. Moreover, in both 2006 and 2012, the data confirmed the very significant differences among the three types of school in connection with students' socioeconomic backgrounds that had been observed in previous research (Escardíbul \& Villarroya, 2009; Mancebón-Torrubia \& Pérez-Ximénez, 2010). The differences of socio-economic composition of the student body between public and publicly-funded private schools, in turn, remained flat between 2006 and 2012.

These findings suggest that the variations in the composition of (public or household) spending had no direct, short-term impact on the student bodysocio-economic composition into different types of schools. Consequently, variations in the education spending required of households (of the magnitude observed here) would not in themselves appear to change the degree of school segregation. Rather, other determinants may be involved, such as macroeconomic dynamics (Williams \& Rossiter, 2004), parents' outlook on education or student selection policies (Gorard, Hordosy \& See, 2013). 


\section{Conclusions}

The findings reported here reveal significant differences in public and household spending per student by type of school as well as changes in the distribution of total spending over the period analysed. There was no increase in socio-economic background-based segregation in the wake of the changes in public and household funding for schools. Such segregation would not then appear to depend only on schooling costs but on a mix of structural and other more specific elements, like the geographical distribution of the population by socioeconomic situation or the parental views on the different kind of schools.

This study is subject to limitations that should be borne in mind when interpreting the findings like the information furnished by governments on public spending by type of school. Some expenditures are not broken down, for instance, while no data is published on public spending on items such as the construction of buildings for publicly-funded private schools, which is erroneously attributed to public school spending only. The diversity of information sources on public and household spending on education restricts comparability largely because they do not always display the same accounting periods.

Even so, the study contains new and relevant information on national education policy and its implications. The findings show that governments' share in school funding was significantly lower at the end than at the beginning of the period except in private schools. Moreover, households' financial burden grew at the same time as cut-backs in public services put more pressure on their economies. This, along with the relative upturn in public spending for publicly-funded private schools, denotes the existence of exogenous privatisation in Spain, a process that merits careful monitoring in the near future. The effects of these trends on the academic performance of social groups should be explored as should the impact on household economies. As non-compulsory stages of education are particularly sensitive to variations in education costs, special attention should be paid to 0-3 early childhood education and post-compulsory secondary education.

\section{References}

Alderman, H., Orazem, P. F., \& Paterno, E. M. (2001). School quality, school cost, and the public/private school choices of low-income households in Pakistan. Journal of Human Resources, 36, 304-326. doi:10.2307/3069661

Ammermueller, A., \& Pischke, J. S. (2009). Peer effects in european primary schools: Evidence from the progress in international reading literacy study. Journal of Labor Economics, 27(3), 315-348.

doi:10.1086/603650

Ball, S. J. (2014). Globalización, mercantilización y privatización: tendencias internacionales en Educación y Política Educativa. Education Policy Analysis Archives, 22(41), 1-13. doi:10.14507/epaa.v22n41.2014

Ball, S. J., \& Youdell, D. (2007). Hidden privatization in public education. Brussels: Education International.

Bayona, B. (2013). Los ejes de la LOMCE. Forum Aragón, 7, 13-15.

Bonal, X. (2002). El balance público-privado en el sistema de enseñanza español: evolución y efectos sobre las desigualdades educativas [The public-private balance in the Spanish education system: evolution and effects on educational inequalities]. Educar, 29, 11-29.

Burch, P. (2009). Hidden markets. The new education privatization. New York: Routledge.

Choi, A., \& Calero, J. (2012). Rendimiento académico y titularidad de centro en España [Academic performance and ownership of the center in Spain]. Revista de Currículum y Formación del Profesorado, 16(3), 31-57. 
Cordero, J. M., Crespo, E., \& Pedraja, F. (2013). Rendimiento Educativo y Determinantes según PISA: una revisión de la literatura en España. [Educational performance and determinants according to PISA: a review of the literature in Spain]. Revista de Educación, 362, 273-297.

doi:10.4438/1988-592X-RE-2011-362-161

Dronkers, J., \& Avram, S. (2010). A cross-national analysis of the relations of school choice and effectiveness differences between private-dependent and public schools. Educational Research and Evaluation, 16(2), 151-175.

Dynarski, S., Hoxby, C., Loveless, T., Schneider, M., Whitehurst, G., \& Witte, J. (2010). Charter schools: a report on rethinking the federal role in education. Washington: The Brookings Institution.

Escardíbul, J. O., \& Villarroya, A. (2009). The inequalities in school choice in Spain in accordance to PISA data. Journal of Education Policy, 24(6), 673-696. doi:10.1080/02680930903131259

Eurydice. (2013). Funding of education in Europe 2000-2012: The impact of the economic crisis. Eurydice Report. Luxembourg: Publications Office of the European Union. doi:10.2797/50340

Fernández, R., \& Muñiz, M. (2012). Colegios Concertados y Selección de Escuela en España: un Círculo Vicioso [Concerted schools and school selection in Spain: a vicious circle]. Presupuesto y Gasto Público, 67, 97-118.

Forman, J. (2007). Do charter schools threaten public education? Emerging evidence from fifteen years of a quasi-market for schooling. University of Illinois Law Review, 3, 839-880.

García, F. J., Olmos, A., Rubio, M., \& Capellán, L. (2014). Sobre agrupamiento, concentración, segregación o guetización escolar: claves para un análisis interpretativo de tales situaciones y procesos. In C. Blanco (Ed.), Movilidad humana y diversidad social en un contexto de crisis económica internacional (pp.253-276). Madrid: Trotta.

Gorard, S., Hordosy, R., \&. See, B. H. (2013). Narrowing down the determinants of between-school segregation: An analysis of the intake to all schools in England, 1989-2011. Journal of School Choice, 7(2), 182-195. doi:10.1080/15582159.2013.791182

Hanushek, E. A. (2013). Financing schools. In J. Hattie \& E. M. Anderman (Eds.), International guide to student achievement (pp.134-136). New York: Routledge.

Hartley, D. (2010). Rhetorics of regulation in education after the global economic crisis. Journal of Education Policy, 25(6), 785-791. doi:10.1080/02680939.2010.504887.

Herrero, C., Soler, A. \& Villar, A. (2013). Desarrollo y Pobreza en España y sus Comunidades Autónomas: el Impacto de la Crisis. Papeles de economía española, 138, 98-113.

Jacott, L., \& Maldonado, A. (2006). The centros concertados in Spain, parental demand and implications for equity. European Journal of Education, 41(1), 97-111. doi:10.1111/j.1465-3435.2006.00249.x

Jenkins, S. P., Micklewright, J. \& Schnepf, S.V. (2008). Social segregation in secondary schools: How does england compare with other countries? Oxford Review of Education. 34(1), 21-37.

doi:10.1080/03054980701542039

Mancebón-Torrubia, M. J., \& Pérez-Ximénez, D. (2007). Conciertos educativos y selección académica y social del alumnado. Hacienda Pública Española, 180, 77-106. 
Mancebón-Torrubia, M. J., \& Pérez-Ximénez, D. (2010). Una valoración del grado de segregación socioeconómica existente en el sistema educativo español. Un análisis por comunidades autónomas a partir de PISA 2006. Regional and Sectoral Economic Studies, 10(3), 129-148.

Mehrotra, S., \& DelaMonica, E. (1998). Household costs and public expenditure on primary education in five low income countries: A comparative analysis. International Journal of Educational Development, 18(1), 41-61. doi:10.1016/S0738-0593(97)00043-6

Ministerio de Educación, Cultura y Deporte. (2014). Economic resources. Public spending. Retrieved from http://www.mecd.gob.es/servicios-al-ciudadano-mecd/estadisticas/educacion/recursoseconomicos/gasto-publico/series.html.

Mourshed, M., Chijioke, C., \& Barber, M. (2010). How the world's most improved school systems keep getting better. London: McKinsey \& Company.

Narodowski, M., \& Moschetti, M. (2015). The growth of private education in Argentina: Evidence and explantions. Compare: A Journal of Comparative and International Educación, 45(1), 47-69.

doi:10.1080/03057925.2013.829348

OECD. (2002). Education at a glance. Glossary. Paris: Author.

OECD. (2012). Public and private schools: How management and funding relate to their socio-economic profile. Paris: Author. doi:10.1787/9789264175006-en.

OECD. (2013). PISA 2012 results: excellence through equity (Volume II): Giving every student the chance to succeed. Paris: Author. doi:10.1787/9789264201132-en

OECD. (2014). Education at a glance 2014: OECD indicators. Paris: Author. doi:10.1787/eag-2014-en.

Patrinos, H. A. (2013). Private education provision and public finance: The Nederlands. Education Economics, 21(4), 342-414. doi:10.1080/09645292.2011.568696

Pérez-Díaz, V., \& Rodríguez, J.C. (2011). Diagnóstico y reforma de la educación general en España. In V. Pérez-Díaz, J. C. Rodríguez, F. Felgueroso y S. Jiménez-Martín (Eds.), Reformas necesarias para potenciar el crecimiento de la economía española (pp. 13-205). Madrid: Civitas-Thompon Reuters.

Rogero-García, J., \& Andrés-Candelas, M. (2014). Gasto público y de las familias en educación es España: diferencias entre centros públicos y concertados. Revista Española de Investigaciones Sociológicas, 147, 121-132. doi:10.5477/cis/reis.147.121.

Salinas, J., \& Santín, D. (2012). Selección escolar y efectos de la inmigración sobre los resultados académicos españoles en PISA 2006. Revista de Educación, 358, 382-405. doi:10.4438/1988-592X-RE-2011358-083.

Sirin, S. R. (2005). Socioeconomic status and academic achievement: a meta-analytic review of research. Review of Educational Research, 75(3), 417-453. doi:10.3102/00346543075003417.

UNESCO. (2008). EFA global monitoring report. Education for all by 2015 will we make it? Oxford University Press.

Valverde, A. J. (2004). La peculiar relación de trabajo de los profesores de enseñanza privada concertada: en particular sobre su régimen salarial. La paga extraordinaria por antigüedad. Temas laborales 73, 291309. 
Villarroya, A. (2003). La financiación pública de la enseñanza privada no universitaria en España. Revista de Educación, 330, 187-204.

Wiborg, S. (2013). Neo-liberalism and universal state education: the cases of Denmark, Norway and Sweden 1980-2011. Comparative Education, 49(4), 407-423. doi:10.1080/03050068.2012.700436.

Williams, J., \& Rossiter, A. (2004). Choice: the evidence. The operation of choice systems in practice: national and international evidence. London: Social Market Foundation.

Wolf, F., \& Zohlnhöfer, R. (2009). Investing in human capital? The determinants of private education expenditure in 26 OECD countries. Journal of European Social Policy, 19(3), 230-244.

doi:10.1177/0958928709104738

Zajda, J. (2006). Introduction: decentralisation and privatisation in education: The role of the state. In J. Zajda (Ed.), Decentralisation and privatisation in education: the role of the state (pp. 3-27). Dordrecht, Netherlands: Springer. 